\title{
The role of language exposure in mediated receptive multilingualism
}

\author{
ANNA BRANETS ${ }^{1}$, DARIA BAHTINA ${ }^{2}$ \\ University of Tartu', University of California at Los Angeles²
}

\begin{abstract}
In this study, we investigate the role of exposure to L2 Russian on comprehension of L3 Ukrainian by speakers of L1 Estonian, using the mediating knowledge of L2 Russian. The experiment involved 30 participants and the following materials: a questionnaire, C-test in Russian, word recognition and text comprehension tasks in Ukrainian. We demonstrate that in mediated receptive multilingualism medium to high levels of L2 exposure boost L3 comprehension regardless of measured L2 proficiency. However, exposure enhanced comprehension only on the word level and not on the text level, highlighting the importance of examining comprehension in a differentiated manner. The same restriction holds for targeted L2-L3 instructions, which were administered as a shortcut to increasing metalinguistic awareness between Russian and Ukrainian: these instructions improved L3 word level but not text level comprehension. Since in the absence of explicit instruction the role of exposure was more pronounced, we argue that exposure and instructions interact depending on the particular configurations of available resources, as language users attempt to understand another language. We conclude that exposure to medium language is a crucial factor that might significantly boost comprehension in the target language through increased metalinguistic awareness, either more directly or by creating opportunities for incidental learning.
\end{abstract}


THE ROLE OF LANGUAge EXPOSURE IN MEDiAted RECEPTIVE ...

Keywords: language exposure; metalinguistic awareness; incidental learning; formal instructions; mediated receptive multilingualism; Estonian; Russian; Ukrainian

\section{Introduction}

Multilingual acquisition is a dynamic and non-linear process that depends on a number of factors affecting what language users know and how they may apply this information to new contexts (Pearson et al. 1997; Herdina \& Jessner 2002; Eilers et al. 2006; David \& Wei 2008; Thordardottir 2011; Bedore et al. 2012; Poulin-Dubois et al. 2013; Jessner 2014; Deanda et al. 2016; Verschik 2017 etc.). Communication is possible in multilingual circumstances even when only limited resources are available to interlocutors since learners' receptive and productive skills develop in different ways. In this study, we explore comprehension as a stage that may precede more encompassing linguistic competence. Extensive previous research on multilingualism asserts that even minimal exposure to target language, implicit knowledge of another language closely related to the target language, and perceived proximity between these languages jointly contribute to third language acquisition (in addition to the above cited works, also Gooskens 2007a; Gooskens et al. 2008; Bahtina-Jantsikene 2013; Swarte et al. 2013; Kaivapalu 2015; Branets et al. 2019; Branets \& Backus 2020).

The communication mode that was investigated in this study is receptive multilingualism (henceforth, RM) when interlocutors use their own language while speaking to each other (Rehbein et al. 2012). This mode is mostly employed (and studied) among speakers of related languages (i.e., inherent RM, such as Estonian-Finnish) or in situations of advanced bilingualism (i.e., acquired RM, such as Estonian-Russian). Estonian (Uralic, Finno-Ugric, Baltic-Finnic) and Ukrainian (IndoEuropean, East-Slavic) are neither related nor have a bilingual community speaking these languages. Nevertheless, speakers of Estonian may reach an understanding of Ukrainian through their knowledge of 
Russian (Indo-European East-Slavic). This is why the mode is termed "mediated receptive multilingualism" (Branets et al. 2019).

One aspect frequently discussed in relation to communicative success in receptive multilingualism is language proficiency. Branets and Backus (2020) in their study on the role of Estonian speakers' language proficiency in Russian in comprehension of Ukrainian, pointed out that linguistic proficiency in Russian helped the Estonian speakers to understand Ukrainian. However, the contribution of lexical and grammatical proficiency in Russian should not be overestimated when it comes to the general understanding of Ukrainian texts. Indeed, language proficiency tests capture only one aspect of linguistic proficiency, while there are also extra-linguistic factors that play a role as for example, language exposure (Branets \& Backus 2020; see also especially the studies conducted in the frame of the MICReLa project, such as Gooskens et al. 2015; Swarte et al. 2013; Gooskens \& Heeringa 2014; Schüppert \& Gooskens 2010, etc.). The same suggestion has been made in a series of other RM studies (Gooskens \& Swarte 2007; Verschik 2012; Bahtina-Jantsikene 2013; Berthele \& Wittlin 2013).

Branets et al. (2019) discussed different types of exposure to Russian in relation to understanding Ukrainian among Estonian speakers. The results of the Ukrainian comprehension tests were affected by four types of language exposure: a place of residence and its language environment, professional domain, a field of study or specialisation, and individual exposure and its frequency. The following pattern was observed: the increased use of Russian outside formal settings was positively correlated with successful completion of tests in Ukrainian, regardless of language proficiency in Russian (Branets et al. 2019: 17-18). This suggests that L2 Russian helps when it is used in everyday life and that language proficiency represents only one aspect in a language user's toolkit, in addition to L2 exposure and possibly other factors that affect comprehension.

Mediated receptive multilingualism is gaining prominence in today's world as more people find themselves in situations when they need to understand a language that they have not learned before. We 
THE ROLE OF LANGUAge EXPOSURE IN MEDIATED RECEPTIVE ...

argue that mediated receptive multilingualism has the potential to facilitate such a learning process. Using experimental settings, we investigate implications of mediated receptive multilingualism on the example of L1 Estonian speakers attempting to understand L3 Ukrainian via their proficiency in L2 Russian (B1 and B2 proficiency levels) and explore which factors are beneficial for establishing various levels of comprehension (vocabulary vs general). In this paper, we specifically focus on language exposure as one of the factors that has the potential to improve comprehension on the word level and on the text level. We hypothesise that L2 exposure can further enhance metalinguistic awareness and through that increase language proficiency in the context of mediated receptive multilingualism. We also explore the impact of formal instruction on L2 Russian - L3 Ukrainian correspondence patterns, to establish whether people faced with such learning tasks in real life would benefit from some targeted language instruction.

The paper is organized in the following way: in the second section, we discuss existing literature on metalinguistic awareness, language exposure, and incidental versus formal learning. In the third section, we introduce our methodological design. In the fourth section, we present the data analysis and discuss to what extent and how implicit and explicit types of language exposure enhance understanding. Finally, we propose several research directions to further our understanding of language exposure in receptive multilingualism.

\section{Factors affecting language learning}

In research on multilingualism, language learning has been conceptualized as a complex dynamic process that among other factors relies on metalinguistic awareness - 'the ability to focus on linguistic form and to switch focus between form and meaning' (Jessner 2008: 275). It is this skill that allows language users to understand a new language beyond already learned lexical forms and syntactic rules. It has been argued that the qualitative difference between monolingual, bilingual, and trilingual 
acquisition, each following category being more efficient in language learning than the preceding group, can be explained with varying degrees of metalinguistic awareness (e.g., De Bot, Jaensch 2013; Herdina \& Jessner 2002). Multilingual language users reach an understanding of the target language by using available resources and switching between form and meaning to find similarities between languages (Jessner 2014; Verschik 2017). Such multilingual experience is a valuable source for creative production and increased cognitive processes (Kharkurin 2012).

In the field of $\mathrm{L} 2$ acquisition, receptive bilingualism is defined not as a language mode but as individuals who can understand the language but not produce it, with the focus on proficiency (Romaine 1989; SherkinaLieber 2015). Sherkina-Lieber (2020: 415-417) distinguishes between receptive bilinguals of mutually intelligible languages (with and without previous exposure) from bilingualism with acquired knowledge (heritage or L2 speakers). In the first group, comprehension without exposure depends on finding similarities between closely related languages, and correlates with linguistic distances while comprehension with exposure is more associated with acquired knowledge. She points out that exposure leads to a more naturalistic acquisition of $\mathrm{L} 2$. In the acquired group acquisition is expected to correlate with higher degrees of exposure and/or instruction, frequency of use, and proficiency.

Such awareness can be understood as a set of knowledge and skills that develop over time, based on prior linguistic and metacognitive knowledge. Some argue that the direct way of metalinguistic knowledge acquisition is through language use (e.g., Schwartz 1993; Sharwood 2004; Ellis 2005). Others claim that formal instructions can help language learners develop metalinguistic skills through attention to relevant linguistic features in the input and through activating knowledge that is otherwise only partially available through exposure (e.g., De Bot, Jaensch 2013; Sanz 2000; Thomas 1988). It has also been argued that awareness of the limited nature of available resources - such as low language proficiency, exposure, or familiarity with the task at hand - motivates language users to recruit more explicit strategies, including those 
THE ROLE OF LANGUAGE EXPOSURE IN MEDIATED RECEPTIVE ...

that rely on metalinguistic awareness (Bahtina-Jantsikene \& Backus 2016). Achieving understanding in the context of limited common ground is a widespread way nowadays that is associated with knowing a language (Blommaert \& Backus 2011) or in our case with language learning. Understanding is managed without prior language instruction using linguistic resources language users already have (e.g., Estonians working in Ukraine who do not take a language course in Ukrainian). Learning has a practical motivation and needs to be done efficiently, which raises the importance of metalinguistic awareness.

Linguistic exposure takes different forms and creates various opportunities to facilitate language learning: language users may take an intense language class, actively participate in cultural activities in the target language or simply be members of a multilingual community and still benefit from a more passive exposure (e.g., Rice \& Kroll 2019 on positive cognitive effects of living in linguistically diverse contexts). In second language acquisition, exposure is known to improve comprehension and production across various aspects of language, ranging from morphosyntax to phonology (e.g., Gathercole 2002; Pearson 2002; Bybee 2001; David \& Wei 2008; Poulin-Dubois et al. 2013). In studies of receptive multilingualism, the role of language exposure is understood to be quite straightforward: the more exposure the language user has to the target language, the better they should perform in comprehending the language. Although previous studies did not show any direct correlation between language exposure and intelligibility (see Gooskens 2006, 2007b; Gooskens \& Hilton 2013), they still considered it as an influential factor. Another study showed that even very limited cross-linguistic exposure among six Slavic languages is positively correlated with intelligibility in these languages (Golubović 2016). This suggests that exposure is among the important predictors in receptive multilingualism.

Vocabulary development is claimed to be particularly responsive to exposure, as exposure can significantly improve comprehension on the word level (Thordardottir 2011). Positive effects are observed even after limited cases of exposure to individual lexical items (Hulstijn et al. 
1996; Rott 1999; Webb 2007). The results are particularly pronounced in experiments testing receptive word knowledge (Pellicer-Sánchez 2016). Krashen $(1982,1994)$ and Truscott $(1996,1999)$ emphasize that even more formal aspects of language, such as grammar, can fully develop only through exposure to the language in a naturally occurring conversation. Kaivapalu (2015) emphasizes the positive role of exposure to different varieties and registers (slang, regional dialects, colloquial use, and archaisms) as resources for improving learning outcomes in receptive multilingualism.

Learning through exposure enjoys a considerable amount of scholarly attention in applied subdisciplines and is also discussed under the rubric of incidental learning (see Malone 2018 for a detailed overview). The term is generally understood as learning without intention to do so (Bruton et al. 2011). In second language acquisition, incidental learning is also defined based on intention, however more narrowly, for instance, learning of a linguistic aspect without any intention of an upcoming test (e.g., Hulstijn 2003; Dörnyei 2009). It can also refer to the degree of consciousness involved in the process, creating a binary opposition between explicit and implicit learning (Ellis \& Loewen 2007). Incidental learning has also been discussed in relation to the acquisition of linguistic items in interaction (Brouwer et al. 2004; Brouwer 2003) and as a by-product of learning about the content (Snow et al. 1992).

While formal instructions can be viewed as the opposite of incidental learning, DeKeyser (2003) suggests there is a more direct relationship between metalinguistic knowledge (more explicit) and spontaneous language use: formulaic knowledge gets entrenched through repeated practice and eventually becomes automatic (more implicit). Many researchers in the field of language learning emphasize the advantages of this kind of implicit learning (Doughty 2003; Ellis 2002; Norris \& Ortega 2000). Explicit attention to specific aspects of language is still claimed to have an immediate effect on language learning outcomes. Golubović (2016) studied the effect of explicit instruction in receptive comprehension in the Czech and Croatian in a pretest-posttest design. The Czech experimental 
THE ROLE OF LANGUAge EXPOSURE IN MEDiAted RECEPTIVE ...

group received explicit instructions while the Croatian did not receive any instructions. The study proved that even a small amount of instruction could significantly increase comprehension: the instruction increased functional and perceived intelligibility of Croatian among Czech participants. Interestingly, participants were also able to transfer the acquired knowledge of written to spoken language (Golubović 2016: 139-152).

Lightbown and Spada (1990) found a difference in language test performance between the groups of students based on the type of explicit instructions provided: focus on vocabulary increased overall comprehension whereas focus on grammar additionally increased accuracy. Language learners who perform well on language tests do not necessarily perform well in communication or spontaneous speech and vice versa (Spada \& Lightbown 2008). These results are in line with studies on language acquisition among children (e.g., Harley, Swain 1984; Swain $1985,1989)$ which demonstrate lower morphology and syntax accuracy among fluent learners in the formal settings compared to language learners immersed in the target language environment. In this context, instructions are the most effective when they combine focus on form and meaning (Spada \& Lightbown 2008).

Multimodal exposure, such as listening to a recording of a text while reading it (Shefelbine 1990), can function as a supplementary strategy to enhance comprehension. Gooskens (2013) pointed out that text recordings in intelligibility tests activate participants' listening perception.

Given these recurrent factors of influence in language learning literature, the aim of this paper is to uncover more details about the potential of mediated receptive multilingualism for L3 learning. In the next sections, we will focus on the implications of language exposure onto different levels of comprehension as well as explore the interplay between exposure and formal instructions. To do so, we will address the following questions:

1) Based on the correlation between a C-test in $\mathrm{L} 2$ and exposure to L2, can we assume that these measures can be used interchangeably, or do they differ? 
2) If L2 proficiency and exposure are not the same, what is the extent to which exposure to L2 can improve understanding on the word level and on the text level of L3?

3) What is the impact of formal instructions about L2-L3 correspondence and when? Is targeted language teaching something to be recommended to individuals faced with such learning tasks in real life?

\section{Methodology and participants}

The experiment consisted of four parts: a sociolinguistic questionnaire (Bahtina-Jantsikene 2013), a C-test (Grotjahn 1987), and a test battery for Ukrainian word recognition (Shumarova 2000) and for overall meaning of Ukrainian texts (Gooskens 2013). The experiments were followed by debriefing interviews to collect participants' comments and explanations (see more in Branets \& Verschik (accepted)). The experiment data is part of a larger study presented in Branets et al. 2019.

The participants were 30 speakers of Estonian as L1 with B1 and B2 proficiency of L2 Russian, 10 male, and 20 female, age ranging from 22 to 59 years. All participants had formal instruction in Russian and had language proficiency certificates on B1-B2 levels and/or were enrolled in language classes at the moment of conducting the experiment in 2017-2018. Most participants were Tallinn university students, seven of them already graduated (see more in Branets et al. 2019). None of the participants had regular direct exposure to Ukrainian, 17 participants reported listening to Ukrainian songs, having Ukrainian friends or relatives, rarely watching Ukrainian channels or checking Ukrainian social media.

Participants were divided into two groups: 10 participants received explicit instructions prior to being tested and 20 participants did not receive any instructions. The instructions included a presentation about similarities and differences between Ukrainian and Russian and audio recordings of the Ukrainian texts. 
THE ROLE OF LANGUAge EXPOSURE in MEDIATED RECEPTIVE ...

The questionnaire was developed based on the materials presented in the study on Estonian-Russian receptive multilingualism by Bahtina-Jantsikene (2013). A total of 16 questions were used to collect information about participants' sociolinguistic background. Apart from questions about gender, age, nationality, education, place of residence, languages spoken in the family, and proficiency in other languages, the questionnaire included information about exposure to Russian and to Ukrainian. Participants were asked to provide a self-evaluation of their proficiency in Russian on a Likert scale, ranging from one to five where 1 corresponds to "I understand, but I can't speak", 2 - "I speak, but I feel some difficulties", 3 - "I can understand everyday talk" 4 - "I speak and write freely" and 5 - "I am fluent in this language".

Participants were also asked about the nature of learning Russian, with an aim to capture the difference between formal and informal learning. Another section of the questionnaire was dedicated to self-reported exposure to Russian and focused on two areas: the frequency of using Russian ("Never", "Every year", "Every month", "Every week", "Every day") and the domain of language use ("At home", "At the university", "In social media: I read the magazine /the newspaper/ news / social media networks", "Free time"). The same questions were asked about exposure to Ukrainian and their language attitudes towards Ukrainian (see Annex 1). ${ }^{1}$

After completing the questionnaire all participants were invited to measure their Russian proficiency with a C-test. The C-test was developed in accordance with the instructions presented by Grotjahn (1987). It includes four short texts with five to six sentences each. Starting from the second sentence, the second half of every second word in the text was missing. The participants' task was to fill in the gaps using the correct lexical and grammatical form, only five minutes were allocated for the completion of each short text. The total number of lexical items is 80 per

1 Annex 1 to the article "The role of language exposure in mediated receptive multilingualism": socio-linguistic questionnaire. DataDOI. http://dx.doi.org/10.23673/ re-295 
individual C-test (20 items per text, four texts in total). For the evaluation of the results, we applied a flexible scoring system that was implemented by Bahtina-Jantsikene (2013: 28). The examples of the scoring system were discussed in Branets \& Backus (2020) and are presented below:

- 1 point: a fully correct answer (e.g., when a participant answered that ${ }^{*}$ Mo... mo... corresponds to мope mor'e 'sea');

- 0.75 points: a correct yet grammatically or semantically imperfect answer, or a near synonym that matches the context $\left({ }^{\star}\right.$ maкоe takoje - SG, NEUT for maкue takije - PL 'such');

- 0.5 points: a misspelled word, only approximating the target (e.g., *omdııхнym otdyhnut for omdaxamb otdyhat' 'to rest');

- 0.25 points: a semantically related but grammatically or contextually incorrect (е.g., ${ }^{\star}$ леченых lechenych for лечение lechenije 'treatment');

- 0 points: an unrelated word or no answer $\left({ }^{\star}\right.$ бpaye brache for брачного brachnogo 'marital').

The main part of the experiment focused on the tasks to measure 1) comprehension of Ukrainian words selected from the texts (Shumarova 2000) and 2) understanding the meaning of the Ukrainian texts (Gooskens 2013). In total, the participants received three Ukrainian texts with additional tasks. The first task was to provide definitions for the words highlighted in the text. There were 55 target words in total: 36 words were cognate words that have the same meaning in Russian, 12 were cognates that have a different meaning or belong to a different register, and seven words were unrelated to Russian. We used the same scoring system used throughout the project (for more examples, see Branets \& Backus 2020; Branets \& Verschik (accepted)):

- 1 point: an entirely correct answer (e.g., when a participant recognizes that Ukrainian допомагають dopomagajut' '(they) help' is the translation of Estonian aitama 'to help');

- 0.75 points: a semantically correct definition presented in an incorrect grammatical form or word class (e.g., cmapicms starist 'old age' translated as vana 'old' instead of vanadus 'old age'); 
THE ROLE OF LANGUAge ExPOSURE in MEDiAted RECEPTIVE ...

- 0.5 points: almost correct meaning (e.g., важливого vazhlyvogo 'important' translated as Estonian kõige tähtsam 'the most important' instead of correct tähtis, oluline 'important');

- 0.25 points: a semantically related lexeme that fits the context but is incorrect (e.g., Ukrainian йщли jshly 'were going' translated as Estonian läks ära 'went away');

- 0 points: a completely wrong answer (e.g., Ukrainian вплив vplyv 'influence' translated as Estonian uurimus 'research') or no answer.

General understanding was measured with a test battery consisting of 36 questions in total: 15 true or false questions ( 1 - correct answer; 0 - incorrect), 15 multiple choice questions ( 1 - correct; 0 - incorrect), and 6 open questions ( 1 - full answer; 0.75 - partial answer; 0.5 - many details left out; 0.25 - relevant but some incongruence with context; 0 false or no answer). More details on the scoring system can be found in Branets et al. (2019: 11).

After all tasks were completed, the participants were interviewed to collect their feedback. The duration of each interview was 10-20 minutes and participants were prompted to share their experiences with regard to task completion. An overview of debriefing interviews is outlined in Branets \& Verschik (accepted).

\section{Data}

The analysis of the data was made using the SPSS Statistics program. All 30 participants with Estonian as L1 and formal instructions in L2 Russian were divided into three groups based on their reported language exposure: low exposure to Russian (1.8-2.4 points), medium (2.5-3.5 points) and high (3.6-4.5 points). ${ }^{2}$ These three exposure-based groups were compared on the success rate of completing the C-test in Russian,

2 Each exposure group included participants with both B1 and B2 proficiency in Russian. This paper considers the correlation between L2 proficiency and exposure. L2 proficiency as the primary factor is discussed elsewhere (see Branets et al. 2019; Branets \& Backus 2020). 
recognition of Ukrainian words and understanding of the meaning of Ukrainian texts. We also tested the role of formal instructions together with language exposure across two groups of participants (one group that received instructions in Ukrainian prior to testing and another group that did not). The analysis was made using the one-way ANOVA analysis to compare the means of the groups and multiple linear regression to distinguish the most influential variables.

\subsection{Language exposure to Russian and C-test in Russian}

We compared the performance in the C-tests in Russian between three groups of participants based on their level of exposure to Russian: Group 1 with low exposure $(n=10$, mean $=43.28$ and $S D=11.66)$, Group 2 with medium exposure $(\mathrm{n}=10$, mean $=57.88, \mathrm{SD}=11.10)$ and Group 3 with high exposure $(\mathrm{n}=10$, mean $58.28, \mathrm{SD}=10.81)$. According to ANOVA analysis, the difference in C-test performance between the three groups is significant $(p<.01)$. Based on the multiple comparisons between groups, both Group $2(p<.02)$ and Group $3(p<.02)$ are significantly better than Group 1 . This suggests that low L2 proficiency and low L2 exposure are comparable.

However, the difference in performance in the C-test in Russian between Group 2 and Group 3 turned out to be not significant $(p>.99$ ), which suggests that medium and high levels of exposure to Russian have comparable impact on language proficiency tests. The minimum and the maximum values of the C-test performance of the Group 1 vary between 20.25 and 53.75 whereas Group 2 and 3 demonstrate less variation in that respect. Their minimum scores are 44.00 and 44.75 respectively but Group 2 has a higher value of the maximum score than Group 3 (77.75 and 73.00 respectively). These results suggest that L2 exposure alone cannot predict L2 proficiency (one of the most recurrent factors listed in $\mathrm{RM}$ research) and it is important to investigate the effect of exposure on direct success in mediated RM. 


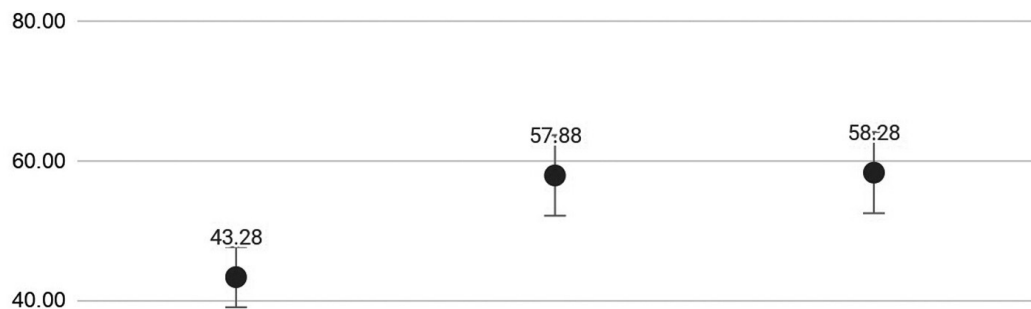

40.00

20.00

$0.00-$ Group 1 "Low exposure" Group 2 "Medium exposure" Group 3 "High exposure"

DIAGRAM 1. C-test mean scores across three exposure levels groups

(low, medium, high)

\subsection{Language exposure and comprehension in Ukrainian}

\subsubsection{Exposure to Russian and word recognition in Ukrainian}

The three exposure-based groups demonstrated the following success rate in the tests on Ukrainian word recognition: Group 1 ( $\mathrm{n}=10$, mean $=27.65, \mathrm{SD}=8.96)$, Group $2(\mathrm{n}=10$, mean $=37.95, \mathrm{SD}=6.17)$, and Group $3(\mathrm{n}=10$, mean $=36.30, \mathrm{SD}=5.23)$. Group 2 with the medium language exposure has a higher mean score than Group 3 with the highest one. ANOVA analysis showed that the difference between these groups is significant $(p<.01)$. According to Tukey HSD multiple comparison, there is also a significant difference in the performance between Group 1 and Group $2(p<.01)$ and Group 1 and Group 3 $(p<.03)$. However, the difference in performance between Group 2 and Group 3 is not significant and the distribution of the mean scores does not suggest a linear correlation between exposure and word level comprehension (see Diagram 2). Therefore, exposure to Russian has a direct 
influence on success rates in Ukrainian word recognition tasks. At the same time, no significant difference between medium and high exposure was determined, which suggests that even limited exposure to a medium language has a positive effect on comprehension in the target language.

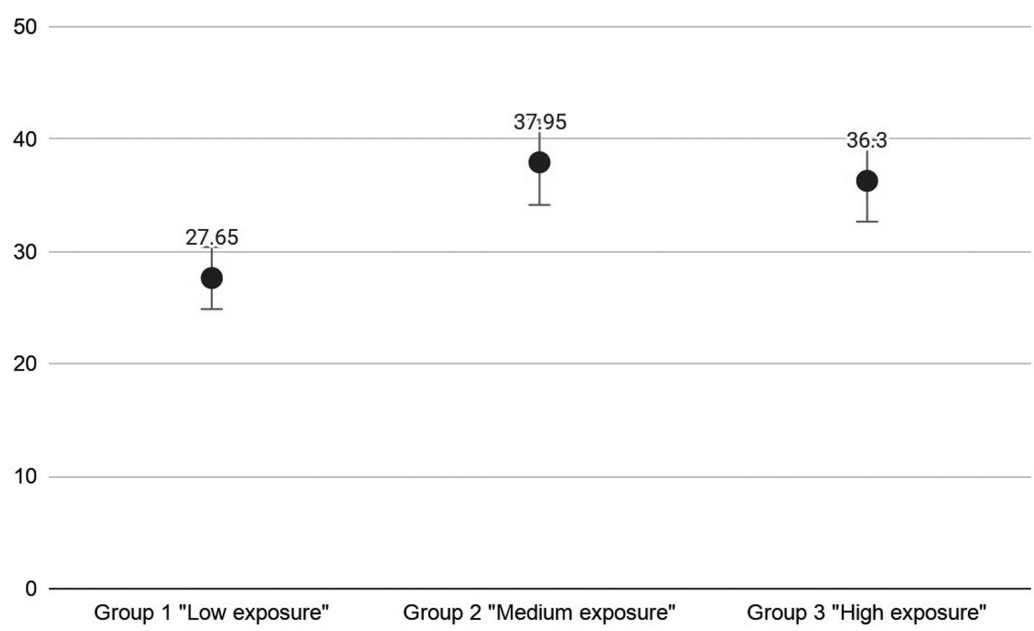

DIAGRAM 2. Word recognition mean scores across three exposure levels groups (low, medium, high)

\subsubsection{Exposure to Russian and understanding} of the texts in Ukrainian

In regards to the language exposure to Russian and understanding of Ukrainian texts as a whole, the results are insignificant with almost equal distribution of text level success between the three groups: Group $1: \mathrm{n}=10$, mean $=29.00, \mathrm{SD}=4.59$; Group 2: $\mathrm{n}=10$, mean $=31.03$, $\mathrm{SD}=4.57$; and Group 3: $\mathrm{n}=10$, mean $=30.67, \mathrm{SD}=3.30$. Therefore, we can claim that exposure to Russian did not affect the overall understanding of Ukrainian texts, limiting its effect only to comprehension on the level of vocabulary. 


\subsection{Language exposure and instructions L2-L3}

We examined the role of exposure to Russian on the C-test in Russian, word recognition and text comprehension tasks in Ukrainian across two conditions: Group A received instructions that explained the similarities and differences between Ukrainian and Russian (e.g., sound transformations, spelling, recording) and Group B received no such instructions.

\subsubsection{Instructions, L2 exposure, and L2 proficiency}

First, we compared the performance on the C-test in Russian between Group A and B and found no significant difference: Group A ( $\mathrm{n}=10$, mean $=58.48, S D=10.09)$ and Group $B(n=10$, mean $=50.48, S D=12.93)$ demonstrated comparable results, which guarantees that any correlations are due to instruction mode and not the C-test. We also looked at the role of exposure to Russian on the C-test in Russian in the two groups separately. We found no significant correlations between C-test and language exposure in the group that received previous instructions $(p>.92)$. This can be in part explained by the fact that all participants in this group happened to have a relatively high level of exposure to Russian (3.0-4.5, falling squarely into the medium and high exposure groups). However, we found a significant pattern between exposure and C-test performance in the group that received no instructions $(p<.01)$. Once again, there was no significant difference determined between medium and high exposure groups. These results indicate that exposure leads to improved C-test results in Russian only in the no-instructions mode; in the instruction mode, the effect disappears.

\subsubsection{Instructions, L2 exposure, and L3 word recognition}

Next, we tested the difference between Group A $(\mathrm{n}=10$, mean $=38.88$, $\mathrm{SD}=6.31)$ and Group B $(\mathrm{n}=20$, mean $=31.51, \mathrm{SD}=7.96)$ in their recognition of Ukrainian words. It becomes apparent from looking at the 
minimum and maximum scores of both groups in this category (Group A: $\min =27.75 \max =49.25$; Group B: $\min =15, \max =44.50$ ) that Group A (with instructions) was significantly more successful than Group B $(p<.02)$. We tested the role of language exposure in Ukrainian word recognition in these two groups separately: there was no significant correlation in the Group A ( $p>.70$ ), which may have been due to insufficient exposure variation in the group (see sections 4.1 on C-test and 4.2 on instructions). The no-instruction Group B demonstrated a clear pattern suggesting a link between exposure and word level comprehension $(p=.052)$.

\subsubsection{Instructions, L2 exposure, and L3 texts understanding}

Finally, we checked the importance of instructions on understanding Ukrainian texts between Group A ( $\mathrm{n}=10$, mean $=30.23, \mathrm{SD}=4.71)$ and Group B $(n=20$, mean $=30.24, S D=3.97)$ and found no significant correlations between exposure and text level understanding, a result consistent with our findings on exposure: both factors exclusively improve word level comprehension in specific contexts.

\section{Discussion}

Research on language acquisition aims to establish factors that reliably predict language learning outcomes. One factor is pre-existing knowledge. When people start to learn a new language from scratch, there may be a lot of knowledge they already have and that can be pressed into service: general knowledge about a language, general experience with learning languages, and knowledge of L1 or an L2 that may transfer to their knowledge of the new language. In this paper, we explored how exposure to the medium language, Russian, facilitates the comprehension of the target language, Ukrainian, in a series of experimental tasks. Other factors that we considered included the interplay between (implicit) exposure and (explicit) instructions to Ukrainian as well as success levels as defined by either word or text level comprehension tasks. 
the ROLE of LANGuAge exposure in MEdiated RECEPtive ...

\subsection{Correlation between exposure and proficiency in $L 2$}

The C-test in our study was designed primarily to measure grammatical and lexical knowledge, which is a proxy to measuring L2 proficiency that is often listed as one of the main factors in RM research. The correlation between exposure to Russian and performance in the Russian $\mathrm{C}$-test is quite natural: exposure to a language increases one's proficiency and improves performance, including in the tests. Our data confirm that language exposure to Russian is directly associated with the results of the C-test in Russian, but mostly when both exposure and proficiency are low. Medium and high exposure groups had very similar C-test results and therefore cannot be used interchangeably. In other words, any correlations between exposure and successful comprehension cannot be attributed to L2 directly, which ratifies further investigation of the influence of exposure on comprehension.

\subsection{Differential impact of $L 2$ exposure on $L 3$ word recognition and text understanding}

Our data showed a correlation of language exposure to L2 Russian to understanding L3 words in Ukrainian. The word recognition task in Ukrainian was used to measure the potential of participants to recognize Ukrainian vocabulary relying on their proficiency in Russian. The correlation of language exposure to Russian and the outcome of the tasks of recognition of Ukrainian words is direct evidence of how mediated receptive multilingualism works: exposure to L2 Russian improves the level of recognition of words in L3 Ukrainian. Exposure to L2 Russian provides a base for learning a related L3 Ukrainian: some knowledge is acquired through exposure even if there was no explicit intention. Therefore, language exposure facilitates some types of incidental learning at the word level through a language medium.

All results discussed in this paper as well as other articles based on the same research project (Branets et al. 2019; Branets \& Backus 
2020) are consistent in one aspect: there is a stark difference between L2 comprehension as measured on the vocabulary and on the overall level of understanding. We established no correlation between overall understanding of Ukrainian texts and exposure to Russian, which suggests there are other factors playing a role in overall comprehension. In this paper, exposure is broadly conceptualized as a context that creates opportunities for incidental learning. The fact that we see a correlation between exposure and word level comprehension but not between exposure and text level comprehension raises the question of what particular linguistic knowledge can be acquired through exposure, especially when we talk about exposure to one language (L2) and mediated comprehension in another language (L3). Research on second language acquisition predicts different patterns for different levels of linguistic information acquisition, such as smaller units like certain morphemes and words being easier to acquire (e.g., the so-called bottleneck hypothesis); studies on receptive multilingualism suggest that understanding of larger units like texts relies on the broad understanding of the context that goes beyond lexical and grammatical knowledge (Muikku-Werner et al. 2012; Kaivapalu 2015; Kaivapalu \& Muikku-Werner 2010). Our data confirm that exposure to Russian, at least at the levels present in the current participants, is beneficial for word level comprehension but insufficient for successful comprehension on the text level.

When we compared groups by exposure - low, medium, and high levels of exposure to Russian - the significance always occurred between low and medium and low and high and not between medium and high levels in both C-test performance and the recognition of Ukrainian words. This suggests that either exposure has a boosting effect from early on or that participants in this experiment were not sufficiently different from one another. As a matter of fact, no participants received a maximum score in terms of exposure: their contact with Russian was either infrequent or limited to one domain even in the high exposure group. Due to low variation present in the tested groups, we also were not able to test the different types of exposure in terms of varying degrees 
THE ROLE OF LANGUAge EXPOSURE IN MEDiAted RECEPTIVE ...

of formality, which would shed more light on the effects of more formal education as opposed to participatory practices in the medium language. However, the non-linear correlation between level of exposure and performance in the experiment suggests that there are additional factors that affect the relation between exposure and comprehension.

\subsection{Impact of formal instruction about L2-L3 correspondence}

Apart from language exposure, instructions present another potential source of learning that is more explicit and typically form-focused. In our study, we investigated the role of instructions together with language exposure to the C-test in Russian, Ukrainian words recognition, and understanding of Ukrainian texts among the two groups of participants: those who received previous instructions and those who did not. The group that received instructions showed no correlation of language exposure to Russian to any of the aforementioned tasks. This could be explained by the fact that participants had only medium and high levels of exposure and there were no participants with low levels of exposure. An alternative interpretation would be to treat exposure and instructions as factors that combined a ceiling effect: explicit instructions level out any implicit knowledge stemming from exposure, leading to all participants having comparable degrees of metalinguistic awareness. In line with that hypothesis, we identified evidence for the beneficial effect of exposure in the group that did not receive instructions: exposure to Russian positively correlated with success in task completion of the C-test in Russian, Ukrainian words recognition but there was no correlation with understanding Ukrainian text as a whole. This might reiterate the fact that exposure becomes even more consequential when other factors facilitating comprehension are limited. 


\section{Conclusions}

We started off with an assumption that factors affecting comprehension in mediated receptive multilingualism would also play an important role in L3 learning. We conclude that in mediated RM exposure to medium language is a crucial factor that might significantly boost comprehension in the target language through increased metalinguistic awareness, either more directly or by creating opportunities for incidental learning. Importantly, we see this effect in relation to both medium and high levels of exposure, but only on the word level and not the text level comprehension. Explicit instructions unequivocally lead to improved performance and in their absence, the role of exposure is even more pronounced. This further supports the general argument that contexts of limited common ground, characterized by low language proficiency and/or lack of formal instruction, make exposure and other similar factors of potential influence even more relevant for language users that recruit any available resources in their attempt to understand another language. While we were not able to obtain all answers about different types of exposure and comprehension due to some limitations of the research, we presented evidence to support the claim that partial language comprehension, a skill needed in many globalized settings, benefits from exposure, especially if that exposure includes opportunities for increasing metalinguistic knowledge, something people can be educated about and trained in. We suggest that such focused training could target not only word level but also general comprehension.

The study used limited data in terms of different configurations of language exposure and language proficiencies as well as exposure formality types, which makes it difficult to generate statistically significant observations on all subsets of questions. The following recommendations would be beneficial for future research. To better understand the nuanced interplay of exposure to Russian and comprehension in Ukrainian, it would be important to expand the pool of participants to incorporate all levels of exposure across all conditions (e.g., in the instruction 
the ROLE of LANGuAge exposure in MEdiated RECEPtive ...

versus no instruction conditions). It would also be crucial to recruit participants with full exposure to medium language: both frequent and not limited to one domain. Testing comprehension based on varying types of formality of exposure will shed more light on the effects of more formal learning as opposed to participatory practices and incidental learning in the medium language. Finally, we would suggest addressing the role of exposure beyond written comprehension by expanding language tests to communication-based tasks.

\section{References}

Annex 1 = Branets, Anna, Daria Bahtina 2021. Annex 1 to the article "The role of language exposure in mediated receptive multilingualism": socio-linguistic questionnaire. DataDOI. http://dx.doi.org/10.23673/re-295

Bahtina-Jantsikene, Daria 2013. Mind Your Languages: Lingua Receptiva in Estonian-Russian Communication. Utrecht: LOT.

Bahtina-Jantsikene, Daria, Ad Backus 2016. Limited common ground, unlimited communicative success: An experimental study into lingua receptiva using Estonian and Russian. - Philologia Estonica Tallinnensis 1, 17-36. https:// doi.org/10.22601/PET.2016.01.03

Bedore, Lisa M., Elizabeth D. Peña, Connie L. Summers, Karin M. Boerger, Maria D. Resendiz, Kai Greene, Thomas M. Bohman, Ronald B. Gillam 2012. The measure matters: Language dominance profiles across measures in Spanish-English bilingual children. - Bilingualism: Language and Cognition 15 (3), 616-629. https://doi.org/10.1017/S1366728912000090

Berthele, Raphael, Gabriele Wittlin 2013. Receptive multilingualism in the Swiss Army. - International Journal of Bilingualism 10 (2), 181-195. https://doi. org/10.1080/14790718.2013.789522

Blommaert, Jan, Ad Backus 2011. Superdiverse Repertoires and the Individual. Multilingualism and Multimodality, 11-32.

Branets, Anna, Ad Backus 2020. L2 knowledge facilitating L3 learning: The role of Russian linguistic factors in understanding Ukrainian by Estonians. Philologia Estonica Tallinnensis 5, 59-86. https://doi.org/10.22601/ PET.2020.05.02

Branets, Anna, Daria Bahtina, Anna Verschik 2019. Mediated receptive multilingualism: Estonian-Russian-Ukrainian case study. - Linguistic Approaches to Bilingualism 10 (3), 380-411. https://doi.org/10.1075/lab.17079.ver 
Branets, Anna, Anna Verschik (accepted). Comprehension of Ukrainian by Estonians via Russian: structural and extra-linguistic aspects. - Russian Journal of Linguistics 4.

Bruton, Anthony, Miguel García López, Raquel Mesa Esquiliche 2011. Incidental vocabulary learning: An impracticable term? - TESOL Quarterly 45, 759-768. https://doi.org/10.5054/tq.2011.268061

Brouwer, Catherine E. 2003. Word searches in NNS-NS interaction: Opportunities for language learning? - Modern Language Journal 87 (4), 534-545. https://doi.org/10.1111/1540-4781.00206

Brouwer, Catherine E., Gitte Rasmussen, Johannes Wagner 2004. Embedded corrections in second language talk. - Rod Gardner, Johannes Wagner (eds.). Second Language Conversations. London: Continuum, 75-92.

Bybee, Joan 2001. Phonology and Language Use. Cambridge Studies in Linguistics 94. Cambridge: Cambridge University Press. https://doi.org/10.1017/ CBO9780511612886

David, Annabelle, Li Wei 2008. Individual differences in the lexical development of French-English bilingual children. - International Journal of Bilingual Education and Bilingualism 11 (5), 598-618. https://doi. org/10.1080/13670050802149200

Deanda, Stephanie, Natalia Arias-Trejo, Diane Poulin-Dubois, Pascal Zesiger, Margaret Friend 2016. Minimal second language exposure, SES, and early word comprehension: New evidence from a direct assessment. - Bilingualism: Language and Cognition 19 (1), 162-180. https://doi.org/10.1017/ S1366728914000820

De Bot, Kees, Carol Jaensch 2013. What is special about L3 processing? - Bilingualism: Language and Cognition 18 (2), 130-144. https://doi.org/10.1017/ S1366728913000448

DeKeyser, Robert M. 2003. Implicit and explicit learning. - Catherine J. Doughty, Michael H. Long (eds.). The Handbook of Second Language Acquisition. Maiden, MA: Blackwell, 312-348. https://doi.org/10.1002/9780470756492. ch11

Doughty, Catherine J. 2003. Instructed SLA: Constraints, compensation, and enhancement. - Catherine J. Doughty, Michael H. Long (eds.). The Handbook of Second Language Acquisition. Maiden, MA: Blackwell, 256-310. https://doi.org/10.1002/9780470756492.ch10

Dörnyei, Zoltán 2009. The Psychology of Second Language Acquisition. Oxford: Oxford University Press. 
THE ROLE OF LANGUAge EXPOSURE IN MEDiAted RECEPTIVE ...

Eilers, Rebecca E., Barbara Zurer Pearson, Alan B. Cobo-Lewis 2006. Social factors in bilingual development: The Miami experience. - Peggy McCardle, Erika Hoff (eds.). Childhood Bilingualism: Research on Infancy through School Age. Bristol, Blue Ridge Summit: Multilingual Matters, 68-90. https://doi. org/10.21832/9781853598715-006

Ellis, Nick C. 2005. At the interface: Dynamic interactions of explicit and implicit language knowledge. - Studies in Second Language Acquisition 27 (2), 305-352. https://doi.org/10.1017/S027226310505014X

Ellis, Rod 2002. Does form-focused instruction affect the acquisition of implicit knowledge? A review of the research. - Studies in Second Language Acquisition 24 (2), 223-236. https://doi.org/10.1017/S0272263102002073

Ellis, Rod, Shawn Loewen 2007. Confirming the operational definitions of explicit and implicit knowledge in Ellis (2005): Responding to Isemonger. - Studies in Second Language Acquisition 29 (1), 119-126. https://doi.org/10.1017/ S0272263107070052

Gathercole, Virginia C. Mueller 2002. Command of the mass/count distinction in bilingual and monolingual children: An English morphosyntactic distinction. - D. Kimbrough Oller, Rebecca E. Eilers (eds.). Language and Literacy in Bilingual Children. Clevedon, UK: Multilingual Matters, 175-206. https://doi.org/10.21832/9781853595721-009

Grotjahn, Rüdiger 1987. How to construct and evaluate a C-test: A discussion of some problems and some statistical analyses. - Rüdiger Grotjahn, Christine Klein-Braley, Douglas K. Stevenson (eds.). Taking Their Measure: The Validity and Validation of Language Tests. Bochum: Brockmeyer, 219-253.

Golubović, Jelena 2016. Mutual Intelligibility in the Slavic Language Area. Dissertation in Linguistics 152. Groningen: University of Groningen.

Gooskens, Charlotte 2006. Linguistic and extra-linguistic predictors of Inter-Scandinavian intelligibility. - Linguistics in the Netherlands 23 (1), 101-113. https://doi.org/10.1075/avt.23.12goo

Gooskens, Charlotte 2007a. The contribution of linguistic factors to the intelligibility of closely related languages. - Journal of Multilingual and Multicultural Development 28 (6), 445-467. https://doi.org/10.2167/jmmd511.0

Gooskens, Charlotte 2007b. Contact, attitude and phonetic distance as predictors of inter-Scandinavian communication. - Jean-Michel Eloy, Tadhg ÓhLfearnáin (eds.). Near Languages - Collateral languages. Actes du colloque international réuni à Limerick. Paris: L'Harmattan: 99-109.

Gooskens, Charlotte 2013. Experimental methods for measuring intelligibility of closely related language varieties. - Robert Bayley, Richard 
Cameron, Ceil Lucas (eds.). The Oxford Handbook of Sociolinguistics. Oxford: Oxford University Press, 195-213. https://doi.org/10.1093/oxfor $\mathrm{dhb} / 9780199744084.013 .0010$

Gooskens, Charlotte, Nanna Haug Hilton 2013. The effect of social factors on the comprehension of a closely related language. - Jani-Matti Tirkkonen, Esa Anttikoski (eds.). Proceedings of the 24th Scandinavian Conference of Linguistics. Joensuu: University of Eastern Finland, 201-210.

Gooskens, Charlotte, Wilbert Heeringa 2014. The role of dialect exposure in receptive multilingualism. - Applied Linguistics Review 5 (1), 247-271. https:// doi.org/10.1515/applirev-2014-0011

Gooskens, Charlotte, Wilbert Heeringa, Karin Beijering 2008. Phonetic and Lexical Predictors of Intelligibility. - International Journal of Humanities and Arts Computing 2 (1-2), 63-81. https://doi.org/10.3366/E1753854809000317

Gooskens Charlotte, Renée van Bezooijen, Vincent J. van Heuven 2015. Mutual intelligibility of Dutch-German cognates by children: The devil is in the detail. - Linguistics 53 (2), 255-283. https://doi.org/10.1515/ling-2015-0002

Gooskens, Charlotte, Femke Swarte 2017. Linguistic and extra-linguistic predictors of mutual intelligibility between Germanic languages. - Nordic Journal of Linguistics 40 (2), 123-147. https://doi.org/10.1017/S0332586517000099

Harley, Birgit, Merril Swain 1984. The interlanguage of immersion students and its implications for second Focus-on-Form language teaching. - Alan Davies, Clive Criper, Anthony P. R. Howatt (eds.). Interlanguage. Edinburgh: Edinburgh University Press, 291-311.

Herdina, Philip, Ulrike Jessner 2002. A Dynamic Model of Multilingualism: Perspective of Change in Psycholinguistics. Clevedon: Multilingual Matters. https://doi.org/10.21832/9781853595547

Hulstijn, Jan 2003. Incidental and intentional learning. - Catherine J. Doughty, Michael H. Long (eds.). The Handbook of Second Language Acquisition. Maiden, MA: Blackwell, 349-382. https://doi.org/10.1002/9780470756492. ch12

Hulstijn, Jan H., Merel Hollander, Tine Greidanus 1996. Incidental vocabulary learning by advanced foreign-language students: the influence of marginal glosses, dictionary use, and recurrence of unknown words. - The Modern Language Journal 80 (3), 327- 339. https://doi. org/10.1111/j.1540-4781.1996.tb01614.x

Jessner, Ulrike 2008. A DST model of multilingualism and the role of metalinguistic awareness. - The Modern Language Journal 92 (2), 270-283. https:// doi.org/10.1111/j.1540-4781.2008.00718.x 
THE ROLE OF LANGUAge EXPOSURE IN MEDiAted RECEPTIVE ...

Jessner, Ulrike 2014. On multilingual awareness or why the multilingual learner is a specific language learner. - Miroslaw Pawlak, Larissa Aronin (eds.). Essential Topics in Applied Linguistics and Multilingualism: Studies in honour of David Singleton. Heidelberg: Springer, 175-184. https://doi. org/10.1007/978-3-319-01414-2_10

Kaivapalu, Annekatrin 2015. Eesti ja soome keele vastastikune mõistmine üksiksõna- ja tekstitasandil: lingvistilised tegurid, mõistmisprotsess ja sümmeetria ['Mutual comprehension of Estonian and Finnish context-free words and texts: linguistic determinants, comprehension process and symmetry']. - Eesti Rakenduslingvistika Ühingu aastaraamat 11, 55-74. https://doi.org/10.5128/ERYa11.04

Kaivapalu, Annekatrin, Pirkko Muikku-Werner 2010. Reseptiivinen monikielisyys: miten suomenkielinen oppija ymmärtää viroa äidinkielensä pohjalta? ['Receptive multilingualism: How Finnish as a first language helps learners to understand Estonian?']. - Lähivertailuja. Lähivõrdlusi 20, 68-97. http:// dx.doi.org/10.5128/LV20.03

Kharkhurin, Anatoliy V. 2012. Multilingualism and Creativity. Bristol: Multilingual Matters. https://doi.org/10.21832/9781847697967

Krashen, Stephen D. 1982. Principles and Practice in Second Language Acquisition. Oxford: Pergamon Press.

Krashen, Stephen D. 1994. The input hypothesis and its rivals. - Nick Ellis (ed.). Implicit and Explicit Learning of Language. London: Academic Press, 45-77.

Lightbown, Patsy M., Nina Spada 1990. Focus-on-form and Corrective Feedback in Communicative Language Teaching. Effects on Second Language Learning. - Studies in Second Language Acquisition 12 (4), 429-448. https://doi. org/10.1017/S0272263100009517

Malone, Jonathan 2018. Incidental vocabulary learning in SLA: Effects of frequency, aural enhancement, and working memory. - Studies in Second Language Acquisition 40, 651-675 https://doi.org/10.1017/S0272263117000341

Muikku-Werner, Pirkko, Annekatrin Kaivapalu, Maisa Martin 2012. Mutual intelligibility in language learning context: Linguistic and strategic determinants of comprehension of Estonian and Finnish. - Matthias Hünig, Uli Reich (eds.). Language and the City: Abstracts. 19th Sociolinguistic Symposium, Berlin, August 21-24. Berlin: Freie Universität Berlin, 266.

Norris, John M., Lourdes Ortega 2000. Effectiveness of L2 instruction: A research synthesis and quantitative meta-analysis. - Language Learning 50 (3), 417-528. https://doi.org/10.1111/0023-8333.00136 
Oscarson, Mats 1989. Self-assessment of language proficiency: Rationale and applications. - Language Testing 6 (1), 1-13. https://doi.org/10.1177/ 026553228900600103

Pearson, Barbara Zurer 2002. Narrative competence among monolingual and bilingual school children in Miami. - D. Kimbrough Oller, Rebecca E. Eilers (eds.). Language and Literacy in Bilingual Children. Clevedon, UK: Multilingual Matters, 135-174. https://doi.org/10.21832/9781853595721-008

Pearson, Barbara Zurer, Sylvia C. Fernández, Vanessa Lewedeg, D. Kimbrough Oller 1997. The relation of input factors to lexical learning by bilingual infants. - Applied Psycholinguistics 18 (1), 41-58. https://doi.org/10.1017/ S0142716400009863

Pellicer-Sánchez, Ana 2016. Incidental vocabulary acquisition from and while reading: An eyetracking study. - Studies in Second Language Acquisition 38 (1), 97-130. https://doi.org/10.1017/S0272263115000224

Poulin-Dubois, Diane, Ellen Białystok, Agnes Blaye, Alexandra Polonia, Jessica Yott 2013. Lexical access and vocabulary development in very young bilinguals. - International Journal of Bilingualism 17 (1), 57-70. https://doi. org/10.1177/1367006911431198

Rehbein, Jochen, ten Thije, Jan D., Verschik, Anna 2012. Remarks on the quintessence of receptive multilingualism. International Journal of Bilingualism, 16 (3), 248-264.

Rice, Kinsey, Judith F. Kroll 2019. English only? Monolinguals in linguistically diverse contexts have an edge in language learning. - Brain and Language 196. https://doi.org/10.1016/j.bandl.2019.104644

Romaine, Suzanne 1989. Bilingualism. Oxford: Blackwell.

Rott, Susanne 1999. The effect of exposure frequency on intermediate language learners' incidental vocabulary acquisition and retention through reading. - Studies in Second Language Acquisition 21 (4), 589- 619. https:// doi.org/10.1017/S0272263199004039

Sanz, Cristina 2000. Bilingual education enhances third language acquisition: Evidence from Catalonia. - Applied Psycholinguistics 21 (1), 23-44. https:// doi.org/10.1017/S0142716400001028

Schwartz, Bonnie D. 1993. On explicit and negative data effecting and affecting competence and linguistic behavior. - Studies in Second Language Acquisition 15 (2), 147-162. https://doi.org/10.1017/S0272263100011931

Sharwood, Smith, M. 2004. In two minds about grammar: On the interaction of linguistic and metalinguistic knowledge in performance. - Transactions of 
THE ROLE OF LANGUAge EXPOSURE IN MEDiAted RECEPTIVE ...

the Philological Society 102 (2), 255-280. https://doi.org/10.1111/j.00791636.2004.00137.x

Schüppert, Anja, Charlotte Gooskens 2010. The influence of extra-linguistic factors on mutual intelligibility: Some preliminary results from Danish and Swedish pre-schoolers. - Barry Heselwood, Clive Upton (eds.). Proceedings of Methods in Dialectology. Bamberger Beiträge zur Englischen Sprachwissenschaft. Frankfurt: Peter Lang, 194-203.

Sherkina-Lieber, Marina 2015. Tense, aspect, and agreement in heritage Labrador Inuttitut: Do receptive bilinguals understand functional morphology? - Linguistic Approaches to Bilingualism 5(1): 30-61. https://doi. org/10.1075/lab.5.1.02she

Sherkina-Lieber, Marina 2020. A classification of receptive bilinguals Why we need to distinguish them, and what they have in common. - Linguistic Approaches to Bilingualism 10 (3), 412-440. https://doi.org/10.1075/ lab.5.1.02she

Shefelbine, John L. 1990. Student factors related to variability in learning word meanings from context. - Journal of Literacy Research 22 (1), 71-97. https://doi.org/10.1080/10862969009547695

Snow, Marguerite Ann, Myriam Met, Fred Genesee 1992. A conceptual framework for the integration of language and content instruction. - Patricia A. Richard-Amato, Marguerite Ann Snow (eds.). The Multicultural Classroom: Readings for Content-Area Teachers. Reading, MA: Addison-Wesley, 27-38.

Shumarova, Nataliia 2000. Мовна компетенція особистості в ситуації білінгвізму ['Individual linguistic competence in the situation of bilingualism']. Kyiv: Видавничий центр КДЛУ.

Spada, Nina, Patsy M. Lightbown 2008. Form-focused instruction: Isolated or integrated? - TESOL Quarterly 42 (2), 181-207. https://doi. org/10.2307/40264447

Swain, Merrill 1985. Communicative competence: Some roles of comprehensible input and comprehensible output and its development. - Susan Gass, Carolyn Madden (eds.). Input in Second Language Acquisition. Rowley, MA: Newbury House, 235-253.

Swain, Merrill 1989. Manipulating and complementing content teaching to maximize second language learning. - TESOL Canada Journal 6 (1), 68-83. https://doi.org/10.18806/tesl.v6i1.542

Swarte, Femke, Anja Schüppert, Charlotte Gooskens 2013. Do speakers of Dutch use their knowledge of German while processing written 
Danish words? - Linguistics in the Netherlands 30 (1), 146-159. https:// doi.org/10.1075/avt.30.11swa

Thomas, Jacqueline 1988. The role played by metalinguistic awareness in second and third language learning. - Journal of Multilingual and Multicultural Development 9 (3), 235-246. https://doi.org/10.1080/01434632.1988.999 4334

Thordardottir, Elin 2011. The relationship between bilingual exposure and vocabulary development. - International Journal of Bilingualism 15 (4), 426-445. https://doi.org/10.1177/1367006911403202

Truscott, John 1996. The case against grammar correction in L2 writing classes. - Language Learning 46 (2), 327-369. https://doi.org/10.1111/j.1467-1770.1996. tb01238.x

Truscott, John 1999. What's wrong with oral grammar correction. - Canadian Modern Language Review 55 (4), 437-456. https://doi.org/10.3138/ cmlr.55.4.437

Verschik, Anna 2012. Practicing Receptive Multilingualism: Estonian-Finnish communication in Tallinn. - International Journal of Bilingualism 16 (3), 265-286. https://doi.org/10.1177/1367006911426465

Verschik, Anna 2017. Language contact, language awareness, and multilingualism. - Jasone Cenoz, Durk Gorter, Stephen May (eds.). Language Awareness and Multilingualism. Cham: Springer, 1-13. https://doi.org/10.1007/9783-319-02325-0_21-2

Webb, Stuart 2007. Learning word pairs and glossed sentences: the effects of a single context on vocabulary knowledge. - Language Teaching Research 11 (1), 63-81. https://doi.org/10.1177/1362168806072463

\section{Anna Branets}

University of Tartu

Jakobi 2, 51005 Tartu, Estonia

anna.branets@ut.ee

\section{Daria Bahtina}

Department of Linguistics

University of California, Los Angeles

335 Portola Plaza, 3125 Campbell Hall

Los Angeles, CA 90095-1543, USA

bahtina@ucla.edu 


\title{
Sihtkeelega kokkupuute roll vahendatud retseptiivses mitmekeelsuses
}

\author{
ANNA BRANETS ${ }^{1}$, DARIA BAHTINA ${ }^{2}$ \\ Tartu Ülikool ${ }^{1}$, California Ülikool Los Angeleses ${ }^{2}$
}

Artiklis analüüsime, kuidas eesti emakeele (L1) kõnelejad mõistavad ukraina keelt (L3) vene keele oskuse toel (L2) ehk millist rolli mängib kokkupuude vene keelega arusaamisel ukraina keelest.

Katses osales 30 inimest ja materjalid koosnesid: küsimustikust, vene keele C-testist ning ukraina keele sõnade äratundmise ja teksti mõistmise ülesannetest. Uuringu tulemused näitasid, et vahendatud retseptiivse mitmekeelsuse kontekstis mõjutab L2-ga kokkupuude L2-st ja L3-st arusaamist kindlal viisil. Kokkupuude vene keelega avaldas positiivset mõju nii vene keele C-testi tulemustele kui ka ukrainakeelsete sõnade äratundmisele. Ukrainakeelsete tekstide mõistmist kokkupuude vene keelega aga märgatavalt ei mõjutanud, mis toob esile, kui oluline on arusaamise hindamine eristaval viisil. Teisalt hõlbustas L3 sõnade äratundmist nii keskmine kui ka kõrgem L2-ga kokkupuute tase, millest järeldub, et isegi vähene kokkupuude suurendab metalingvistilist teadlikkust. Katse sisaldas kahte sellisest hüpoteesist lähtuvat lisatingimust, mille põhjal formaalsed juhised võimaldavad teist, konkreetsemat õppimisallikat: mõned osalejad said eelnevalt formaalseid juhiseid ukraina keelest ja teised mitte. Need selged juhised aitasid kahtlemata kaasa L3-st arusaamisele ning nende puudumisel oli L2-ga kokkupuute roll veelgi märgatavam. Võib järeldada, et kui keelekasutaja üritab teisest keelest aru saada, siis eelmainitud tegurid, nii otsesemad kui ka kaudsemad, toimivad üksteisest sõltuvalt ja muutuvad vähem või rohkem märgatavaks olenevalt saadaval olevate ressursside konkreetsetest asetustest.

Võtmesõnad: sihtkeelega kokkupuude; metalingvistiline teadlikkus; juhuslik õppimine; formaalsed juhised; vahendatud retseptiivne mitmekeelsus; eesti keel; vene keel; ukraina keel 